\title{
Mitigating unintended impacts? The effects of premiums for underserved populations in performance-funding policies for higher education
}

\author{
Denisa Gándara ${ }^{\mathrm{a}}$ \\ Southern Methodist University \\ Amanda Rutherford ${ }^{\mathrm{b}}$ \\ Indiana University
}

Performance funding is an increasingly prevalent policy state officials use to allocate a portion of state funds to public colleges and universities. Researchers have begun to evaluate the effect of these policies, finding bleak evidence of their effectiveness in yielding intended outputs and suggesting the policies may even result in limited college access for underserved students. There may also be differences in policy effects depending on performance-funding policy designs, which vary considerably across states. Of particular interest to this study are premiumsfinancial bonuses to institutions - for promoting access and success for specified underserved student groups. Using difference-in-differences models and an original dataset on premiums in funding models, this study evaluates the impact of premiums for underserved students in performance-funding models on selectivity and the enrollment of minority and low-income students at four-year universities from 1993-2014. We find that the share of both low-income and Hispanic students increases in institutions with performance-funding premiums for underserved students compared to institutions subject to performance funding without such premiums. Effects vary depending on premium type and longevity. The findings also reveal unexpected, negative effects of premiums on Black student enrollments. Our findings suggest that, by incorporating premiums, performance-funding model designers might prevent, minimize, or reverse the negative consequences of performance funding on vulnerable student groups. However, given variation in premium effects across student groups, performancefunding model designs should be tailored to local contexts.

Keywords: higher education; finance; policy design; state policy; policy analysis; performance funding; performance-based funding; outcomes-based funding; performance management

Note: Author names are listed in alphabetical order. Each author contributed to this manuscript equally.

aAssistant Professor; Education Policy and Leadership; 3101 University Blvd Ste. 345, Box 114, Dallas, TX; +1 (214) 768-4779; dgandara@ @mu.edu. b Assistant Professor; School of Public and Environmental Affairs; 1315 E. Tenth Street, Bloomington, IN; +1 (812) 856-4647; aruther@indiana.edu. 


\section{Mitigating unintended impacts? The effects of premiums for underserved populations in performance-funding policies for higher education}

\section{Introduction}

Performance-funding models that state policymakers use to determine appropriations for public higher education institutions are prevalent across the United States. In early 2016, 46 states were considering, transitioning to, or operating a performance-funding program, leaving only four states without any policy activity around this funding method (Friedel, Thornton, D’Amico, \& Katsinas, 2013; Jones, 2014; National Conference of State Legislatures, 2014). ${ }^{1}$ The diffusion of performance-funding policies represents a shift away from longstanding funding methods that were primarily incremental and based on student enrollments, semester credit hours, or other input-oriented measures of volume (McKeown-Moak, 1999).

Given performance-funding policies' salience across states, higher education observers and scholars have begun to scrutinize these funding models. Researchers have found that, in the aggregate, performance funding has not resulted in improved graduation rates or degrees awarded (e.g., Hillman, Tandberg, \& Gross, 2014; Hillman, Tandberg, \& Hicklin-Fryar, 2015; Sanford \& Hunter, 2011; Shin, 2010; Shin \& Milton, 2001; Volkwein \& Tandberg, 2008). A few isolated studies suggest more promising (or at least mixed) outcomes, especially for longstanding policies, than the preponderance of the literature. For example, Rutherford and Rabovsky (2014) found that newer (2.0) programs might become more promising if given more time, although performance funding is also associated with potential decreases in graduation rates over time for earlier (1.0) policies. Also related to implementation time, Tandberg and Hillman (2014) reported that policies that are in place for at least seven years can be linked to increases in the

\footnotetext{
${ }^{1}$ One author tracked news articles relating to performance funding between November of 2013 and September of 2016 using Google Alerts. The Alerts sent an e-mail notice when an article that mentioned performance- or outcomes-based funding for higher education, postsecondary education, colleges, or universities appeared online.
} 
number of baccalaureate degrees produced. At the community college level, performance funding was associated with increased completions in four states and decreases in completions in six other states (Tandberg, Hillman, \& Barakat, 2014).

Amidst this mixed but largely bleak evidence regarding the success of performancefunding policies in producing intended outcomes, recent research has begun to document possible unintended impacts associated with these policies (Lahr, Pheatt, Dougherty, Jones, Natow, \& Reddy, 2014). For instance, a study of performance funding in Indiana reported that some institutions increase selectivity when subject to performance funding (Umbricht, Fernandez, \& Ortagus, 2015). Similarly, Kelchen and Stedrak (2016) found that institutions subject to performance funding receive less Pell Grant revenue than those not funded by this type of model. Another study examined how different groups of students generate funding for community colleges under a performance-funding model in Texas (McKinney \& Hagedorn, 2017). The authors found that traditionally underserved students (GED holders, African American, older adult, and part-time students) yield fewer performance funds for colleges, raising concerns that institutions may be discouraged from serving these students. The aggregate findings on unintended impacts of performance funding in higher education are troubling, particularly since populations that have traditionally been underserved in higher educationparticularly racial/ethnic minorities and low-income students - may face an even more limited path to pursuing higher education under performance-funding regimes. Because educational attainment and institutional prestige are strongly linked to labor market outcomes (Thomas \& Zhang, 2005; Zhang, 2005), the inequality perpetuated through decreased access has broad implications for individuals and society. 
Some critics of these presumably unintended consequences argue that state governments should avoid performance-funding policies, especially since they are laborious and have not produced intended results (e.g., Hillman, 2016). On the other hand, proponents of performance funding who acknowledge these policies' unintended impacts suggest that the solution is not necessarily to abandon the policies but rather to improve the policy structures (e.g., Jones, 2014; Tierney, 2014). Indeed, there is immense variation in the designs of performance-funding policies across states, and some structures may be more conducive to unintended impacts, including decreased access, than others. To prevent limiting access to historically underserved groups, for example, some funding models now include premiums-financial bonuses designed to reward institutions for the enrollment and success of targeted student populations. These premiums tend to focus largely on low-income and racial/ethnic minority students; other less common premiums target older adult, academically underprepared, in-state, or veteran students. For instance, under Tennessee's first outcomes-based funding model (adopted in 2010), each university earned an additional $40 \%$ for every adult (25 and older) and Pell-eligible student who graduated or met one of the other performance metrics in the model. That is, each Pell-eligible and older adult student would yield 1.4 points for meeting each performance metric for the institution they attended, compared to 1 point for students who were not Pell-eligible or classified as adults.

Some performance funding proponents argue that including these premiums in funding models can help avoid negative unintended consequences, such as creaming. Illustratively, in a policy paper commissioned by the Lumina Foundation for Education, Boilard (2016) observes, "effective outcomes-based funding models recognize that some students are harder to educate than others, and combat the incentive to 'cherry pick' only the easier (less-costly) students by 
funding at-risk or underserved students at a higher rate" (p. 12). Likewise, a report by HCM Strategists urges state policymakers to assign, within funding models, "extra weight to graduating at-risk, low-income or underrepresented students in their [performance-funding] systems to guard against providing institutions an incentive to restrict access...in order to boost completion rates" (Snyder, 2015, p. 23).

Despite growing advocacy for incorporating premiums for underserved students in performance-based funding models, previous research has not examined systematically the effects of these individual policy components on underserved students' access to college. This is surprising given emerging evidence that performance-funding programs can result in increased selectivity and decreased enrollment of students from traditionally underserved groups (Kelchen \& Stedrak, 2016; Umbricht, Fernandez, \& Ortagus, 2015). To address this void in the literature, this study examines how the inclusion of premiums for underserved students in performancefunding policies affects institutional selectivity and the share of enrollment of these student populations. We focus on public four-year institutions, where we are more likely to observe increases in selectivity. Specifically, this study answers two research questions. First, among four-year institutions in states with performance funding, do premiums for underserved populations in performance-funding policies affect institutions' selectivity? Second, do premiums for underserved populations in performance-funding policies affect institutions' demographic profiles (i.e., the proportion of Black, Hispanic, and low-income students)?

By addressing these questions, this study sheds light on whether premiums help mitigate unintended impacts, particularly increased selectivity and decreased enrollment of groups that higher education institutions have underserved historically. In light of widespread interest in performance-funding policy adoption and numerous states' pursuit of performance-funding 
policy redesign (e.g., Colorado in 2016 and Tennessee in 2015), the findings from this study should inform future deliberations and decisions concerning performance-funding policy adoption and design.

\section{Previous Research on Performance-Funding Policy Impacts}

Although research on the intended effects of performance-funding policies has focused on immediate, intermediate, and ultimate impacts (Dougherty \& Reddy, 2013), the findings related to ultimate impacts are most relevant for this analysis. Overall, existing literature does not corroborate performance-funding policies' effectiveness in increasing degrees awarded or graduation rates (e.g., Hillman, Tandberg, \& Gross, 2014; Rutherford \& Rabovsky, 2014; Sanford \& Hunter, 2011; Shin, 2010; Shin \& Milton, 2001; Tandberg, Hillman, \& Barakat, 2014; Volkwein \& Tandberg, 2008). Studies on this topic have generated markedly mixed results. The most promising findings come from two studies that find the potential for positive effects in longstanding programs at four-year institutions nationally (Tandberg \& Hillman, 2014) and at two-year institutions in Washington (Hillman, Tandberg, \& Hicklin-Fryar, 2015). In the latter case, the authors found increases in short-term certificates - and declines in longer-term credentials. As the authors suggest, this might signal that students are pursuing easy-to-obtain credentials in lieu of certificates and associate's degrees. This behavior may not be desirable, since short-term certificates have less value in the labor market than long-term certificates and degrees (Liu, Belfield, \& Trimble, 2015).

As noted previously, in addition to weak evidence of performance-funding policies' effectiveness at producing increases in completions, scholars have found evidence of negative unintended consequences. Qualitative studies, for instance, have found that institutions narrow 
their mission (Bell, 2005; Dougherty \& Hong, 2006; Jenkins, Ellwein, \& Boswell, 2009). This line of research has also found evidence of creaming, or focusing efforts on groups most likely to affect performance measures while denying services to others, in Tennessee (Banta, Rudolph, van Dyke, \& Fisher, 1996; Colbeck, 2002). Recent quantitative research has corroborated these findings. For example, Umbricht, Fernandez, and Ortagus (2015) reported that institutions in Indiana became more selective (i.e., by enrolling students with higher ACT scores and lowering admission rates), relative to private institutions in the state and to institutions of geographic proximity without performance funding. The performance-funding policy they examined also resulted in fewer minority students enrolled in public institutions subject to the policy. Similarly, Kelchen and Stedrak (2016) reported that at four-year institutions, Pell-Grant revenues per fulltime equivalent student (FTE) decreased under performance-funding programs, suggesting that institutions may have intentionally altered enrollment behaviors (by limiting access to lower income students) in response to performance funding.

These findings are not limited to the context of higher education but are consistent with literature on performance management in many other contexts. Contemporary discussions of performance management in the public sector often reference New Public Management reforms, which peaked in the mid-1990s. This movement sought to make the public sector more efficient via promising more discretion and creativity in the process as long as specific outcomes were met (Hood, 1995). Public administration scholars have studied various types of performance accountability policies in a range of policy arenas including education, crime and policing, public health, and child support. A recent meta-analysis of performance management revealed that these systems have a small but positive average effect on performance outcomes in public organizations where they are employed (Gerrish, 2016). There is, however, considerable 
variability in the effects of performance-management systems. Moreover, numerous studies have uncovered the negative, sometimes unintended, consequences of performance-management systems. For example, previous studies of performance management have revealed the practice of cream-skimming, or limiting service to clients more likely to show positive outcomes, within organizations subject to performance management (Adams, Heywood, \& Rothstein, 2009; Heckman, Heinrich, \& Smith, 2002; Shen, 2003). Others have documented evidence of gaming performance-management systems to reap greater rewards in the context of public health (Bevan \& Hood, 2006) and public schools (Jacob, 2005). Previous research also shows that some organizations narrow their missions under performance management (Adams et al., 2009) and that positive effects observed in the short run can quickly wane over time (Werner, Kolstad, Stuart, \& Polsky, 2011). Drawing on this line of research, Hillman (2016) warns of the potential pitfalls of performance management policies in the context of higher education.

\section{Performance-Funding Policy Designs}

Performance-funding policies can be broken down into many constituent parts. These include the indicators used to measure performance, which most commonly focus on retention and completion metrics followed by other measures such as job placement rates, wages of graduates, faculty productivity, external research funding, and transfers. Formulas also vary in their degree of complexity. For instance, while Arizona weighs each of three metrics by 33 percent, South Carolina's policy, now discontinued, included over 30 metrics.

Other policy design considerations include premiums for priorities identified by policy makers and other stakeholder groups. For instance, some policies include premiums for highly desirable areas of study like Science, Technology, Engineering and Math (STEM) fields or 
nursing degrees. Of specific interest for this study are premiums for populations traditionally underserved in higher education. These groups include low-income students, older adult students, ethnic minorities, "at-risk" students, and students who are academically underprepared. These premiums are included in some, but not all, performance-funding policies.

Those involved in designing performance-funding policies typically include premiums for underserved students for one or more of three reasons, as revealed in a multiple case study analysis of Colorado and Texas (Gándara, 2016). All three approaches assume that campus actors are rational and self-interested and that they will be motivated by the possibility of increasing their funding under a performance-based model. The first reason for including a premium is to incentivize institutions to increase the enrollment of specific student populations or to seek to maximize these groups' success in the metrics included in the model. Two recent studies have found that institutions respond to premiums by focusing on the success of underserved groups (Li \& Zumeta, 2016; Ness, Deupree, \& Gándara, 2015). Relatedly, the second reason for including such premiums is to address the concern that performance-funding policies will limit access to higher education, particularly for certain student populations. The purpose for including a premium for a specific type of student is that campus actors will be less likely to shirk by cherry-picking students in their recruitment and enrollment decisions.

The third motivation for including premiums for underserved students in funding models is to protect higher education institutions that stand to lose funding under a proposed performance-based model without the inclusion of premiums. Specifically, policy designers might add premiums that will automatically award more funds to certain institutions given their current levels of inputs (e.g., high proportion of low-income students) or outputs (e.g., STEM degrees awarded). Policy designers might include premiums in an effort to shift funds toward 
specific institutions for one of two reasons: (1) to gain buy-in for the new model from the institutions that benefit from the premium or, (2) out of concern that institutions might face considerable fiscal challenges absent the funding premium (Gándara, 2016). Consistent with the first two motivations for including premiums for underserved students, we might expect increases or maintenance of enrollment levels (i.e., avoiding decreases in enrollments) for these populations when premiums for underserved students are included in performance-funding models.

\section{Conceptual Framework}

This study draws conceptual insights from agency theory and the policy-instrument literature. Agency theory focuses on the problems that arise when a principal relies on an agent to pursue a desired outcome on her behalf. In this relationship, the principal has formal power over the agent, as in the case of employers with employees (Eisenhardt, 1989). With performance-funding policies, policymakers are the principals and campus representatives are the agents. Because not all of the agents' efforts are observable — that is, principals have limited access to information regarding agents' processes, motivations, and capabilities - principals tend to focus on agents' performance outputs (Eisenhardt, 1989).

The key challenges that emerge under a principal-agent relationship are due to: (1) asymmetric information and (2) divergent interests between principals and agents (Eisenhardt, 1989; Moe, 1984). In higher education, policymakers do not have complete information on the strategies and actions of campus-level actors, especially because colleges and universities are such complex organizations (Kivistö, 2008). In addition to information asymmetry, problems emerge because principals and agents often have different values for maximizing their own self- 
interests (Moe, 1984). In the case of state policymakers and campus representatives, campus actors might be more motivated to enhance their institutions' prestige (e.g., improve their position in national rankings), whereas policymakers might be more interested in increasing degree production to boost the state's economy (Kivistö, 2008).

To address the problem of divergent interests, the principal can employ various control mechanisms, including incentives that can be negotiated between principals and agents (Miller, 2005), with the hope that such incentives will lead the agent to comply with pursuing the principal's interests (Van Slyke, 2007). Premiums within performance-funding policies constitute one such incentive that policymakers might employ to compel agents (here, campus actors) to adhere to the intent of the policy. Alternatively, as mentioned above, the premium may not be an inducement but rather a mechanism for distributing funds to specific institutions. If the premium is an inducement and the incentive is successful in addressing information asymmetry and value differences, institutions should avoid becoming more selective or decreasing the enrollment of underserved students.

Coupled with principal-agent theory and the performance management literature, this analysis garners insights from literature on inducements. Inducements are one type of policy instrument, or technique, used by policymakers to attain their preferred goals (Howlett, 2005), and they are what we commonly think of as carrots (rewards) or sticks (penalties). Other instrument categories include mandates, regulations, capacity-building tools, and subsidies (McDonnell \& Elmore, 1987; Schneider \& Ingram, 1990). We conceptualize performancefunding premiums as specialized inducements embedded within performance-funding policies (which are inducements themselves since they consist of financial incentives to achieve desired outcomes) (Dougherty, Jones, Lahr, Natow, Pheatt, \& Reddy, 2014). 
Stone (2002) outlines three conceptual elements of inducements: the opportunities for slippage from design to implementation; the strategic and political nature of inducement receivers (targets of inducements); and the relationship—both the complementarity and tensions - between multiple inducements. The third element is most relevant for this analysis. For some institutional leaders, the incentive to prioritize the enrollment and success of underserved students may compete with the incentive to increase performance in other metrics (e.g., graduation rates) rewarded in the model. A purely rational approach—and one by which maximizing funding is the sole motivation for campus leaders' behavior-might suggest that campus officials will balance their efforts spent on admitting and supporting underserved students on one hand and improving graduation rates on the other to yield the greatest financial returns. If increased enrollment of underserved students, who campus actors may deem to be at higher risk, ultimately decreases funding on more highly valued metrics, these actors may conclude that the premiums are less worthy of their attention. Indeed, researchers in Tennessee found that some campus officials concluded that the $40 \%$ premium in the 2010 version of the funding model was not enough to prioritize older adult and low-income students (Ness, Deupree, \& Gándara, 2014). In a revised version of the model, the coordinating board in that state increased the value of the premiums (Tennessee Higher Education Commission, 2015). Within this conceptual framework of the principal-agent problem and the advantages and limitations of inducements, this study examines the unique effect of premiums for underserved populations (inducements embedded within an inducement) on access for low-income and minority students. 


\section{Data Sources}

The empirical analysis for this study focuses on changes within institutions between 1993 and $2014 .^{2}$ We examine whether, among institutions in states that implemented performancefunding policies at some point in our time period, institutions with premiums for underserved (i.e., racial/ethnic minority, low-income, or older adult) students experience changes in selectivity or the composition of the student body. This means that we are not comparing institutions with performance funding to institutions without performance funding but that we are comparing institutions with performance-funding policy premiums to institutions with performance-funding policies that do not include premiums. Whether institutions subject to policies with premiums are significantly different from institutions in states with no performance funding is outside the scope of this paper (though it is also an interesting question), because we are mostly interested in whether premiums can soften possible adverse effects for underserved student groups.

We obtained data to test these questions from multiple sources. First, we collected data on whether state policies placed some priority (in the form of a funding premium) on one or more of a number of underrepresented groups (e.g., low-income and minority students) from state records and previous research. Second, we acquired data on institutional and student characteristics from the Integrated Postsecondary Education Data System (IPEDS). Third, we gathered data on state economic data from the Bureau of Labor Statistics. We discuss the data in more detail below.

A growing literature on performance-funding policies in higher education has developed over the last decade. To determine which public four-year institutions were covered by

\footnotetext{
${ }^{2}$ Our starting point is 1993 since that was the first year in which we identified a premium (for minority students in Tennessee).
} 
performance-funding policies across the fifty states, we referenced the work of others (i.e., Dougherty \& Natow, 2015; Rutherford \& Rabovsky, 2014). To fill voids and address discrepancies in these datasets, we also examined other studies and state records - often in the form of legislation, PowerPoint presentations, and state budget documents (e.g., General Appropriations Acts in Texas). Importantly, we coded institutions as covered by performancefunding policies only in the years when the policies were operational (funding was tied to performance metrics, according to state, system, or institutional budget reports) rather than when they were passed by the state legislature. ${ }^{3}$

Beyond coding for the presence of any performance-funding policy, we drew on the aforementioned sources to code whether the state included premiums for non-majority student groups, specifically minority, low-income, or older adult groups for each year of policy implementation. We were only interested in those policies that include mandatory metrics for underserved student populations, not cases in which single institutions select this type of metric. For example, if a state allows an institution to select three criteria for performance review, the institution may or may not select a metric related to low-income students; this optional metric would not be counted as a premium for underserved students. In cases where past research or information from the state was unclear, we consulted via e-mail with policy experts and states' higher education offices (e.g., Oregon's Higher Education Coordinating Commission and the Indiana Commission for Higher Education).

\footnotetext{
${ }^{3}$ One possible limitation of this study is whether there is any anticipatory effect that is a result of the policy being considered but not yet passed. We chose to focus on policy operationalization because: (1) there is sometimes a significant lag between policy adoption and operationalization, (2) policy adoption (at the legislative level) is separate from the adoption of a model design, and (3) recent research has found that at least some campus actors speculate that a performance-funding policy will not become operationalized after adoption. For the aforementioned reasons, we cannot assume that campus officials will respond to a policy's adoption (at the legislative level).
} 
Information detailing the results of this coding process appears in Table 1 below. The column listing performance funding years signals what data are in our overall sample (while this table reflects information at the state level, our data are reported as institution-years within these states). Columns noting the presence of various premiums indicate when treatment periods begin as well as the length of time such treatments are in place. In addition to the columns shown in Table 1, we also create a dichotomous variable for instances where both minority and lowincome student premiums exist to determine if the effect sizes are smaller or larger when the two are combined; this measure will overlap to some extent with the any premium measure, but the latter is also coded " 1 " when an adult student premium exists. We do not consider premiums for older adult students separately in our analyses below given that only a few states have considered this type of premium for a very short period of recent years.

$<<$ Insert Table 1 Here >

\section{Research Design}

Our analyses include 5,552 institution-year observations, including 4,114 observations for 187 institutions in the treated group and 1,408 observations for 64 institutions in the control group. Given many discussions of whether performance funding may lead to the tightening of admissions and student access, we first test whether premiums are linked to selectivity, which we operationalize as the institutional admission rate, or the share of applicants who were accepted by the institution in each year. The higher this share, the less selective the institution (in other words, larger shares of students are admitted). It should be noted that these variables are not available across the entire period of time we are interested in examining but instead are only provided for 2001-2014 $(\mathrm{n}=2,653)$. We then test the influence of premiums on the enrollment of 
three groups_-Black students (the number of all students who are Black, logged), Hispanic students (the number of all students who are Hispanic, ${ }^{4}$ logged), and low-income students (the percent of students who received a Pell Grant while in school). Measuring the enrollment of lowincome students at an institution is perhaps the most challenging of the three groups given what data are available over time; we use Pell Grant data made available from 1997-2014 through the College Scorecard. ${ }^{5}$

We then include a number of variables that may influence selectivity or student enrollment. These include the size of the institution measured by total student enrollment (logged), instructional expenditures per student (logged), in-state tuition price (logged), the percent of undergraduate students who are enrolled part-time, and the student-faculty ratio (logged). Multiple variables are logged to prevent outlier variables from having a disproportionate influence on reported relationships in our models. At the state level, we control for the state unemployment rate because higher unemployment rates can both threaten funding for higher education and send more individuals back to school (McLendon, Hearn, \& Mokher, 2009; Tandberg, 2010).

The primary focus of our research is to investigate the extent to which premiums for underrepresented students affect the enrollment of underserved populations in participating institutions compared to those institutions operating under performance-funding policies without premiums. While we cannot know with certainty what would have happened in institutions in the absence of these policy premiums, we can use Difference-in-Differences (DiD) regression to

\footnotetext{
${ }^{4}$ More specifically, this variable as reported in IPEDS refers to all students who identify as a person of Mexican, Puerto Rican, Cuban, Central or South American or other Spanish culture or origin, regardless of race.

${ }^{5}$ The College Scorecard data also include information on the percent of undergraduates who received a Pell Grant each year. However, this variable is only available from 2008-2014, which would leave out over half of the time period we are interested in reviewing.
} 
consider changes in Black, Hispanic, and low-income student groups pre and post treatment in these cases. We can compare such trends to a control group that consists of institutions in states that implemented performance funding at some point during the 1993-2014 time period but did not include premiums in these policies. The relationships discussed below cannot be viewed as entirely causal and should be interpreted carefully. We also encourage additional research that can replicate and further test the effects of policy premiums so validation or correction of relationships can occur.

After identifying our treatment and control groups across the time period of interest, we control for both institution and year fixed effects in all models to control for unobserved trends over time that are not already included in the model. Institution fixed effects account for unobserved, stable characteristics of institutions such as flagship status or institutional location. Year fixed effects account for over-time changes that influence all institutions such as federal policies related to student aid or national economic booms and busts. This allows for a model specification of:

$$
\mathrm{Y}_{\mathrm{it}}=\alpha+\beta_{1}(\text { treat x post })_{\mathrm{it}}+\beta_{2}(\text { policy time })_{\mathrm{it}}+\gamma \mathbf{X}_{\mathrm{it}}+\eta_{\mathrm{t}}+\delta_{\mathrm{i}}+\varepsilon_{\mathrm{i}}
$$

where $\mathrm{Y}$ is one of the key dependent variables (Black, Hispanic, low-income enrollment) in each institution $(i)$ for each year of time $(t)$ and $\alpha$ is the intercept. Because of the presence of different time periods in which treatment begins, the (treat $\mathrm{x}$ post) interaction is set to equal one for all institutions in the years during and following the adoption of a premium (see also Tandberg, Hillman, \& Barakat, 2014). Next, the variable (policy time) accounts for the number of years a performance-funding premium has be in place for each institution. $\mathbf{X}_{\text {it }}$ represents a vector of included covariates. Finally, $\eta_{t}$ represents year $(t)$ fixed effects, $\delta_{i}$ represents institution $(i)$ fixed effects, and $\varepsilon_{\mathrm{i}}$ represents an error term that is clustered by institution to better adjust for 
autocorrelation and heteroscedasticity (Wooldridge, 2002). We ran this model in parallel fashion for cases of any premium (minority, low-income, and/or adult premium), minority premium, low-income premium, and minority and low-income premiums.

It is also important to consider the assumption of parallel trends for $\mathrm{DiD}$ models. In other words, it is possible that there are differences between the treatment and control institutions that could influence which institutions are treated or unrelated trends that allow one group to look different from the other in pre-treatment periods. Here, we implement robustness checks by manipulating the treatment and control groups. Prior work has often assessed robustness checks by restricting the control group to institutions in neighboring states or institutions in the same region (Tandberg, Hillman, \& Barakat, 2014; Kramer, Holcomb, \& Kelchen, 2017). For instance, if institutions in the treatment group were primarily clustered in the Southeast, the ideal comparison group may not include institutions in the Northwest. These robustness checks are less ideal in our case, however, as not all states are included in the analysis. Twenty-four states did not implement performance funding for colleges and universities between 1993 and 2014 and are thus entirely excluded from the analysis. For the remaining 26 states, narrowing the control group to include border states that have performance-funding polices without premiums at some point during our sample time period means that only South Carolina is dropped from the control group. As institutions in the treatment group are also widely dispersed geographically, narrowing by region does not achieve a difference in the control group.

We test two robustness checks in addition to excluding institutions in South Carolina from the control group. Our second approach stems from studying figures that compare average trends for treated institutions in a state to the average trends for all institutions in the control group. In other words, we look at average trends for treated institutions across 17 individual 
states and compare these trends to average trends in the control group that spans 10 states (some institutions in Minnesota are in the treatment group while others are in the control group). In this exercise, pre-treatment trends for Black and Hispanic enrollment in institutions in New Mexico were clearly different from the control group. As such, we also run our models excluding institutions in this state. Finally, as a third robustness check, we run data with additional treatment and control institutions that are excluded from the primary analysis because of missing data. This unbalanced panel consists of 7,080 institution-year observations, of which 5,033 are in the treatment group and 2,047 are in the control group.

Findings for these three robustness checks are consistent with the findings reported in the primary analysis below (tables not shown here). Substantive results did not vary when either South Carolina or New Mexico institutions were excluded from the models. Similarly, DiD regression with unbalanced and balanced panels resulted in similar conclusions, providing support that the parallel trends assumption is met.

\section{Findings}

Table 2 includes descriptive statistics for all variables in the analysis. All four dependent variables appear quite similar across both treatment and control groups. While the standard deviations for premium coverage in treated states is substantial, the average duration of these policies is less than two years. This is likely due to many of these policies being adopted in very recent years. Among control variables, only the percent of part-time undergraduates appears to have slight differences; institutions affected by policy premiums, on average, have 4.5 percent more part-time students compared to institutions in the control group.

$$
<<\text { Insert Table } 2 \text { Here }>>
$$




\section{Premium Effects on Selectivity}

In Table 3, we test whether premiums have any discernible effect on institutional selectivity (measured as the percent of applicants who are admitted to the institution). Given the limited availability of data on the dependent variable, this table only covers the period of 20012014. Across all models, coefficients for the any premium variable are no different than zero. Substantively, while some studies have suggested performance-funding policies may be linked to higher levels of selectivity, premiums within these policies do not appear to have any additional effect to heighten or lessen any change in selectivity. This raises questions regarding whether these premiums will in fact be meaningful for the underserved student groups they are intended to benefit. On the other hand, the duration variable for institutions with both minority and lowincome premiums is positively related to admission rates; each year the premium is in place, the admission rate increases by .78 percentage points, all else equal. This could suggest that where multiple premiums are in place for longer periods of time, institutions will be less selective as compared to those institutions subject to performance funding without premiums for underserved students groups. It may also indicate that counteracting general performance policies may be difficult, since we only observe a significant coefficient were multiple premiums are in place. Overall, few control variables have a meaningful effect in the models, though instructional spending per student is consistently linked to higher admissions rates, which means more access for students.

\section{$<<$ Insert Table 3 Here >>}

Of course, there are multiple ways to measure the selectivity of an institution. One possibility that can be tested with available data is standardized test scores. To determine if our finding is robust, we test our models with the $25^{\text {th }}$ and $75^{\text {th }}$ percentile scores for ACT and SAT 
standardized exams. Verbal/English and math scores were added together to create a variable for the $25^{\text {th }}$ percentile score and $75^{\text {th }}$ percentile score for each test. To create one variable, we convert ACT scores to SAT scores using a College Board concordance table where SAT scores were not reported but ACT scores were available. In these robustness checks, a slightly different effect is detected. For all eight models for premium treatments as related to $25^{\text {th }}$ and $75^{\text {th }}$ percentile scores, coefficients for the treatment interaction and duration variables are negative in sign, which would signal that students with lower scores may be admitted. However, only the treatment variables for minority student premiums are statistically significant; these premiums lower $25^{\text {th }}$ and $75^{\text {th }}$ percentile scores by 9.99 and 8.96 , respectively, on the 1600 SAT scale. These minority student premiums also generate a significant treatment coefficient (-6.45) for any premium (similar to Model 1 in Table 3) as related to $75^{\text {th }}$ percentile scores. These models support the notion of a wider opening of doors to students in institutions with premiums in performance-funding models relative to those with no premiums in their models.

\section{Premium Effects on Black Student Enrollment}

The results from the analysis examining the effect of performance-funding premiums on Black student enrollment in four-year public institutions appear in Table 4. These models now include data from 1993-2014. Contrary to expectations, the only significant coefficients for our key independent variables are negative in sign. Low-income student premiums have an immediate negative effect on the enrollment of black students (ln) while the duration of minority student premiums and minority student plus low-income student premiums also appear to have a negative effect on black student enrollment. More specifically, in Model 3, institutions with a policy premium for low-income students are linked to having eight percent fewer Black students than other institutions with performance-funding policies without premiums. It is also worth 
noting that the duration variable for low-income student premiums just misses meeting standard levels of significance $(\mathrm{p}=.13)$, indicating that there may be some slow rate of recovery for black student enrollment over the length of time in which these premiums are implemented. Still, there appears to be some evidence that Black students are worse off in institutions with performance funding with premiums than without premiums. In considering what might explain these unexpected findings, one possibility is that institutions may focus on non-black minority and low-income students when responding to some types of premiums, but micro-level explanations may vary by state or institution. ${ }^{6}$ Though not the focus of this analysis, total enrollment (ln), the share of part-time undergraduates, and the faculty-student ratio (ln) are all positively correlated with total Black student enrollment.

$<<$ Insert Table 4 here $>>$

\section{Premium Effects on Hispanic Student Enrollments}

Next, we turn to Hispanic students to determine whether patterns noted for Black student enrollment are similar or different for other student groups. While Hispanic students are still a minority group in many jurisdictions in the United States, this population is growing at a much faster rate than other racial/ethnic groups, creating the possibility of a larger supply of students for some institutions in states with performance-funding premiums. Results examining the influence of premiums on the share of Hispanic students appear in Table 5.

\footnotetext{
${ }^{6}$ Though not shown here, we also ran parallel models for White students and Asian students. While there is a significant negative effect for White students in the case of low-income premiums as well as any type of premium (driven by the low-income finding), there is also a small positive effect for the duration variable in the low-income premium model. There also appears to be a small negative effect on White students over time where minority student premiums are in place, as compared to institutions with performance funding and no premium. Immediate effects are largely insignificant for Asian students, though some p-values are strong. Like White students, Asian student enrollment also gains over time in the case of low-income student premiums. As such, it appears lowincome premiums are positively related to the enrollment of all student groups via the duration variable; only the coefficient for black enrollment does not meet standard levels of significance at $\mathrm{p}=.13$.
} 
The findings in Table 5 are somewhat mixed but have positive implications overall. Premiums have little to no immediate effect on Hispanic student enrollment with the exception of low-income student premiums. Similar to Table 4, it appears that low-income premiums (Model 3) have a slight negative immediate effect on Hispanic student enrollment. However, this immediate effect is balanced by a positive growth in the Hispanic student population as the premium's duration grows in years. In Model 3, each year of a low-income student premium is associated with institutions with premiums enrolling .80 percent more Hispanic students compared to institutions with performance funding and no premium. This is stronger in Model 4, where simultaneous premiums for minority and low-income students translates to 1.9 percentage point increase per year compared to non-premium performance funding institutions, all else equal. While other premiums appear to have no immediate effect, these policies also indicate over-time growth in the Hispanic population relative to those institutions without a policy premium (Models 1 and 4). This suggests that institutions with performance-funding premiums for underserved students may initially look very similar to institutions not subject to such premiums but that Hispanic enrollment may be boosted over time as the policy is cemented and further implemented. Finally, it is also interesting to note that in neither Table 4 nor Table 5 do premiums specific to racial and ethnic minority students appear to be helpful in enrolling these students compared to institutions that are not subject to these premiums, at least for the data sample and time period studied here. Minority premiums are, however, associated with slight decreases in White student enrollments (see footnote 6). On the other hand, when minority student premiums are coupled with low-income student premiums, enrollment gains over time appear to be stronger than when only one of these premiums is present. This could be related to signaling by the state as well as larger incentives to recruit underrepresented student populations. 


\section{$<<$ Insert Table 5 Here >>}

Similar to Table 3, overall enrollment is positively related to the logged number of Hispanic students in an institution. Table 5 also detects consistent positive effects for the percent of part-time undergraduate students and the faculty-student ratio. In-state tuition prices and state unemployment rates are negatively related to the logged number of Hispanic students enrolled in institutions.

\section{Premium Effects on Low-Income Student Enrollments}

In Table 6, the same models are conducted for our proxy of low-income students - the share of students who have ever received a Pell Grant while in school, available from 1997-2014. At the institutional level, instruction per student is positively related to this variable while, at the state level, higher unemployment rates mean higher levels of Pell revenue for the institution, all else equal. Diverting from Tables 4 and 5, results show consistent positive effects of premiums for low-income students. None of our measures of premiums have an immediate direct effect, though $\mathrm{p}$-values are quite strong in Models 1 and 3 at $\mathrm{p}=.103$ and $\mathrm{p}=.115$, respectively. This indicates that premiums for low-income students indeed have some modest consequence for enrolling more low-income students in institutions relative to institutions with performancefunding policies that are void of such premiums. Things look more promising when examining the duration variables. In three of the four cases, the length of the premiums is significantly and positively related to the share of students who have received a Pell Grant while in school. On average, for any type of premium (Model 1), the enrollment of low-income students is 9.3

percentage points higher for performance funding institutions with premiums compared to those without premiums. 
Multiple accounts may explain why we observe different effects for low-income students than for Black and Hispanic students. First, it may be that institutions are able to recruit lowincome students across majority and minority student groups. The extent to which they do this may depend on a number of factors including, but not limited to, the demographics and socioeconomic strata of geographically proximate students and the explicit and implicit biases of individual employees and the culture of the institution at large. It might also be the case that findings vary based on our proxy measure for low-income students; this measure captures a percentage whereas the other two measures capture a logged count. Further, the low-income measure does not extend to years prior to 1997 . To examine the issue of measurement, we conducted a robustness check of these models using total Pell Grant revenue (ln) from IPEDS similar to the approach taken by Kelchen and Stedrak (2016). These models (not shown here) show an immediate negative effect in the case of minority student premiums; low-income premiums have no immediate treatment effect but are tied to increases in Pell Grant revenue as the policies are in place over time via the length variable. This latter finding is similar to results in Table 6.

\section{$<<$ Insert Table 6 Here $>$}

\section{Discussion and Conclusion}

The goal of this study was to determine whether specific components of performancefunding policies_-premiums for underserved students — have any effect on institutional selectivity and the enrollment of underrepresented or disadvantaged groups. According to theories related to principal-agent relationships and the use of inducements, we would expect that minority and low-income student premiums, if offering meaningful incentives, would increase 
the enrollment of these particular groups at institutions. In terms of principal-agent models, institutions may respond to a call for enhancing access or may simply be interested in maximizing funding from the policy, but either motivation would have the potential to increase access for groups targeted by the policy premiums.

We find support for this expectation for Hispanic and low-income students, particularly when these premiums are sustained over time. We also observe an unexpected negative effect of premiums on Black student enrollments. Low-income premiums had a small significant effect on Hispanic enrollments both immediately following implementation and over time. Low-income premiums also had a large significant effect on low-income student enrollments over time (though they did not have an immediate effect using standard thresholds of statistical significance). Models with minority premiums did not have a significant effect on either Hispanic or low-income students.

Models with premiums for both minority and low-income students had the strongest significant effects across all models, especially when sustained for longer periods of time. One explanation for this result is that the inclusion of both premiums provides a clear signal that the state prioritizes these student groups. Alternatively, institutions may be responding to the stronger financial incentive; in light of our conceptual framework, we expect institutional actors to try to maximize the funding they receive from the state.

For Hispanic and low-income students, the effects of models with both minority and lowincome premiums were positive. However, for Black student enrollments, these models (and all others with premiums) were associated with a negative effect, with models with both a minority and low-income premium having the strongest (in this case, negative) effect. One interpretation of this unexpected finding on Black student enrollments is that institutions might respond to 
premiums by enrolling other types of students for whom they receive premium funding (e.g., low-income student and other minority students). Understanding the causes of this relationship require additional micro-level investigation. For example, the definition of minority students varies across funding models, and diversity among aspiring college students in some states is larger than others. Future work might consider how these premiums are operationalized and the effect of varying definitions on enrollment outcomes.

While some of the substantive interpretations of the findings in our analysis may appear small, we argue that they are quite meaningful given that existing research suggests that some institutions covered by performance-funding policies act in ways that limit access and equity for underrepresented groups (Kelchen \& Stedrak, 2016; Lahr et al., 2014; Umbricht, Fernandez, \& Ortagus, 2015). That we find positive linkages between premiums and the some types of underserved students in institutions means that there are some structural levers by which negative (un)intended consequences of performance-funding policies may be minimized or reversed. This also indicates that practitioners, whether institutional actors or state-level policymakers, should be encouraged to consider such premiums within new or existing performance-funding policies should they wish to avoid negative consequences for vulnerable student groups. In other words, there may be tools and policy mechanisms available to help tailor incentive structures and curb cream-skimming. That said, given the result of Table 4 on Black student enrollments, there is likely not a one-size-fits all solution but rather premium structures that may need to be tailored by state or institution in order to avoid hurting groups or creating trade-offs among underserved groups.

Beyond premiums for underserved students in performance-funding models, policymakers have an array of options for designing higher education funding models (Gándara, 
2016). One approach that, like premiums, would account for student demographics consists of input-adjusted models (Miller, 2016). This type of model takes as inputs select student demographic characteristics within each institution. As such, it accounts for the reality that some institutions serve students who have historically lower probabilities of completing their degrees and who may require additional services. In addition, as Hillman (2016) has proposed, policymakers could consider funding colleges and universities for capacity building. This funding scheme would have the advantage of avoiding downward spirals that may result when institutions have limited resources before performance funding is implemented, and their funding is cut further under the new model. A third option for higher education funding is equity-based funding, which involves providing more funding to those institutions with the most need, approximating vertical equity (Berne \& Stiefel, 1984). These funding options should be considered as either complements or supplements to performance-funding methods.

One criticism of the present study might be that it takes too much of a general view of these policies. While we argue that our approach is certainly helpful to understand the average reaction to policy premiums, we also recognize this could mask a few cases in which institutions responded quite well to policy premiums by enrolling significantly more minority or low-income students as well as a few cases where institutions responded negatively to such premiums by creating additional barriers for minority or low-income students. For example, it is important to consider that policymakers may include premiums for students groups for different reasons, and it is possible that institutions respond differently to premiums based on the policy designers' intentions (especially since campus officials are often part of the policy design process). On one hand, these premiums may be created to provide institutions in a state that already enrolls large proportions of underserved groups an avenue by which to meet performance-funding criteria. If 
this is the case, and campus officials understand that this is the intent of the premiums, then we might expect very little change in response to the premiums from any institution. Of course, because there is a financial incentive attached to the premium, we could still observe changes in institutional behavior to maximize funding through premiums, regardless of policymakers' intentions for including the premiums.

On the other hand, the purpose of premiums could be to incentivize all institutions in a state to recruit and retain students targeted through a premium. The goal, then, would be to encourage all institutions to recruit and support, for example, minority or low-income students. Regardless of policy intentions, well-resourced flagship or land grant institutions may not need to respond to these premiums because they already meet performance criteria through other avenues within the performance-funding model (e.g., graduation rates) or through supplemental sources of funding (e.g., research grants and contracts). Indeed, for some institutions, focusing on other elements of a performance-funding policy (e.g., graduation rates)—perhaps at the expense of premiums - might yield the highest financial returns. In this case, if the institution's focus is primarily on maximizing funding, we may not expect any increases in underserved student enrollments. Returning to our earlier discussion of policy instruments, for some institutions the broader performance-funding policy inducement might be a stronger incentive than specific types of premium inducements.

Future research should explore how our average effect can be further parsed out among institutional or geographic groups. We also encourage additional micro-level research to determine if and when the goals of states with premiums differ. In particular, additional research should aim to determine how institutions vary in their reactions to premiums (e.g., in decreasing, increasing, or maintaining the share of underserved groups) according to policymakers' intended 
goals (e.g., increase underserved student enrollments, mitigate creaming, or shift funds to institutions that already serve these students).

An additional limitation of this study is that we do not consider the specific weighting of premiums in each performance-funding policy, but only determine whether such premiums exist. As such, our study only speaks to treatment (and not dosage) effects. Further, we recognize that timing matters. Policies developed in the last five years may have different premiums structures that could be more or less effective than those policies developed at the beginning of our time period; more time may be needed to determine whether more recent premiums have particular effect on student enrollment compositions. Last, even where institutions may attempt to recruit certain types of students, these students must still choose to matriculate to the institution. For institutions with reputations that may appear unwelcoming to underrepresented students, institutions' efforts may require much longer periods of time to produce change.

Even in light of these caveats, this study illuminates the importance of considering premiums in performance-funding policies and suggests that such premiums can be effective in changing institutional behavior. This study is a first attempt to push this research forward, and it provides evidence that these premiums may indeed be meaningful for helping underserved student groups, particularly where general performance-funding policies can hurt these groups. Practitioners and scholars alike should continue to examine the development of premiums in new funding policies across the states. 


\begin{tabular}{|c|c|c|c|c|c|}
\hline State $^{1}$ & PF Years & $\begin{array}{c}\text { Any } \\
\text { Premium }\end{array}$ & $\begin{array}{l}\text { Minority } \\
\text { Premium }\end{array}$ & $\begin{array}{l}\text { Low Income } \\
\text { Premium }\end{array}$ & Adult Premium \\
\hline Arkansas & 2013-2014 & & & & \\
\hline Arizona & 2012-2014 & & & & \\
\hline Colorado & $\begin{array}{l}\text { 1994-1997, } \\
2000-2003\end{array}$ & $\begin{array}{l}\text { 1994-1997, } \\
2000-2003\end{array}$ & $\begin{array}{l}\text { 1994-1997, } \\
2000-2003\end{array}$ & 1994-1997 & \\
\hline Florida & 2014 & 2014 & & 2014 & \\
\hline Illinois & 2012-2014 & $2012-2014$ & 2012-2014 & $2012-2014$ & $2012-2014$ \\
\hline Indiana & 2007-2014 & $2010-2014$ & & $2010-2014$ & \\
\hline Kansas* & 2004-2014 & & & & \\
\hline Kentucky & 1994-1998 & & & & \\
\hline Louisiana* & 2010-2014 & & & & \\
\hline Maine & $2013-2014^{2}$ & 2013-2014 & & & 2013-2014 \\
\hline Michigan & 2011-2014 & 2014 & & 2014 & \\
\hline Minnesota & $\begin{array}{l}2007-2009 \\
2011-2014\end{array}$ & $2012-2014^{3}$ & 2012-2013 & 2014 & \\
\hline Missouri & $\begin{array}{l}\text { 1993-2002 } \\
2013-2014\end{array}$ & 1993-2002 & 1993-2002 & & \\
\hline Mississippi & 2014 & 2014 & & 2014 & 2014 \\
\hline New Jersey & 1998-2002 & & & & \\
\hline New Mexico & 2012-2014 & 2012-2014 & & $2012-2014$ & \\
\hline Ohio & 1997-2014 & $1997-2014$ & & $1997-2014$ & \\
\hline Oklahoma & 2012-2014 & $2012-2014$ & & $2012-2014$ & \\
\hline Oregon & $\begin{array}{l}2007-2009 \\
2011-2014\end{array}$ & $\begin{array}{l}\text { 2007-2009, } \\
2011-2014\end{array}$ & $\begin{array}{l}2007-2009 \\
2011-2014\end{array}$ & & \\
\hline Pennsylvania & $2000-2014^{4}$ & 2012-2014 & 2012-2014 & $2012-2014$ & \\
\hline South Carolina & 1997-2002 & & & & \\
\hline South Dakota & 2005, 2011 & & & & \\
\hline Tennessee & 1993-2014 & $\begin{array}{l}\text { 1993-1996, } \\
\text { 2011-2014 }\end{array}$ & 1993-1996 & 2011-2014 & 2011-2014 \\
\hline Texas & 2008-2011 & 2008-2011 & & $2008-2011$ & \\
\hline Virginia* & 2005-2014 & $2005-2014$ & 2005-2014 & $2005-2014$ & \\
\hline Washington & 1996-1998 & & & & \\
\hline \multicolumn{6}{|c|}{$\begin{array}{l}{ }^{*} \text { These states have performance contracts. We include these since like other performance-funding models, } \\
\text { performance contracts directly link funding to performance and are intended to change behavior at the campus } \\
\text { level. } \\
\text { le } \\
{ }^{1} \text { While performance-funding systems were discussed for SUNY and CUNY in New York, these are not coded } \\
\text { here due to a lack of performance funding equations and observed implementation. } \\
{ }^{2} \text { The program in ME only applies to universities in The University of Maine System. } \\
{ }^{3} \text { In MN, minority student premiums only applied to institutions in the Minnesota State Colleges and Universities } \\
\text { System in } 2012 \text { and 2013, while low-income student premiums applied only to University of Minnesota } \\
\text { institutions in } 2014 \text {. } \\
\text { } \\
\text { dFor PA, policies are only applicable to PASSHE institutions. Remaining institutions in PA are excluded from the } \\
\text { data as institutions not influenced by performance-funding policies during the time period in our sample. }\end{array}$} \\
\hline
\end{tabular}




\begin{tabular}{|c|c|c|c|}
\hline & $\begin{array}{c}\text { All } \\
\text { Institutions } \\
(\mathrm{SD}) \\
\end{array}$ & $\begin{array}{l}\text { Premium } \\
\text { Institutions } \\
(\mathrm{SD}) \\
\end{array}$ & $\begin{array}{l}\text { Non-Premium } \\
\text { Institutions } \\
(\mathrm{SD})\end{array}$ \\
\hline Admit Rate (only 2001-2014) & $\begin{array}{c}72.63 \\
(14.51)\end{array}$ & $\begin{array}{c}72.06 \\
(14.21)\end{array}$ & $\begin{array}{c}74.02 \\
(15.15)\end{array}$ \\
\hline Black Students (ln) & $\begin{array}{c}6.22 \\
(1.48)\end{array}$ & $\begin{array}{c}6.17 \\
(1.56)\end{array}$ & $\begin{array}{c}6.33 \\
(1.19)\end{array}$ \\
\hline Hispanic Students (ln) & $\begin{array}{c}5.44 \\
(1.61)\end{array}$ & $\begin{array}{c}5.46 \\
(1.70)\end{array}$ & $\begin{array}{c}5.39 \\
(1.32)\end{array}$ \\
\hline Ever Received Pell (only 1997-2014) & $\begin{array}{c}61.56 \\
(14.12)\end{array}$ & $\begin{array}{c}61.19 \\
(14.42)\end{array}$ & $\begin{array}{c}62.70 \\
(13.10)\end{array}$ \\
\hline Duration of Any Premium & $\begin{array}{c}0.89 \\
(2.47)\end{array}$ & $\begin{array}{c}1.20 \\
(2.80)\end{array}$ & $\begin{array}{c}0.00 \\
(0.00)\end{array}$ \\
\hline Duration of Minority Premium & $\begin{array}{c}0.30 \\
(1.27)\end{array}$ & $\begin{array}{c}0.40 \\
(1.45)\end{array}$ & $\begin{array}{c}0.00 \\
(0.00)\end{array}$ \\
\hline Duration of Low-Income Premium & $\begin{array}{c}0.98 \\
(2.98)\end{array}$ & $\begin{array}{c}1.32 \\
(3.39)\end{array}$ & $\begin{array}{c}0.00 \\
(0.00)\end{array}$ \\
\hline Duration of Minority + Low-Income Premium & $\begin{array}{c}0.15 \\
(0.92)\end{array}$ & $\begin{array}{c}0.20 \\
(1.06)\end{array}$ & $\begin{array}{c}0.00 \\
(0.00)\end{array}$ \\
\hline Enrollment (ln) & $\begin{array}{c}9.09 \\
(0.92)\end{array}$ & $\begin{array}{c}9.09 \\
(0.97)\end{array}$ & $\begin{array}{c}9.10 \\
(0.74)\end{array}$ \\
\hline Instruction per student $(\ln )$ & $\begin{array}{c}8.37 \\
(0.56)\end{array}$ & $\begin{array}{c}8.37 \\
(0.59)\end{array}$ & $\begin{array}{c}8.36 \\
(0.45)\end{array}$ \\
\hline Percent Part-Time Undergraduate Students & $\begin{array}{c}28.27 \\
(19.28)\end{array}$ & $\begin{array}{c}29.41 \\
(20.25)\end{array}$ & $\begin{array}{c}24.92 \\
(15.64)\end{array}$ \\
\hline Sticker Price (ln) & $\begin{array}{c}8.16 \\
(0.58)\end{array}$ & $\begin{array}{c}8.18 \\
(0.55)\end{array}$ & $\begin{array}{c}8.10 \\
(0.64)\end{array}$ \\
\hline Faculty-Student Ratio (ln) & $\begin{array}{c}3.35 \\
(0.64)\end{array}$ & $\begin{array}{c}3.37 \\
(0.68)\end{array}$ & $\begin{array}{c}3.31 \\
(0.48)\end{array}$ \\
\hline State Unemployment Rate & $\begin{array}{c}5.90 \\
(1.87)\end{array}$ & $\begin{array}{c}5.87 \\
(1.92)\end{array}$ & $\begin{array}{c}6.01 \\
(1.71)\end{array}$ \\
\hline Observations & 5522 & 4114 & 1408 \\
\hline
\end{tabular}




\begin{tabular}{|c|c|c|c|c|}
\hline & $\begin{array}{c}\text { Any } \\
\text { Premium }\end{array}$ & $\begin{array}{l}\text { Minority } \\
\text { Student } \\
\text { Premium }\end{array}$ & $\begin{array}{c}\text { Low- } \\
\text { Income } \\
\text { Student } \\
\text { Premium }\end{array}$ & $\begin{array}{l}\text { Minority } \\
\text { and Low- } \\
\text { Income } \\
\text { Premium }\end{array}$ \\
\hline Premium Treat $\mathrm{x}$ Post & $\begin{array}{l}-1.567 \\
(1.287)\end{array}$ & $\begin{array}{l}1.962 \\
(1.663)\end{array}$ & $\begin{array}{l}-0.212 \\
(1.314)\end{array}$ & $\begin{array}{l}1.987 \\
(1.567)\end{array}$ \\
\hline Duration of Premium (years) & $\begin{array}{l}0.213 \\
(0.181)\end{array}$ & $\begin{array}{l}0.199 \\
(0.303)\end{array}$ & $\begin{array}{l}0.158 \\
(0.190)\end{array}$ & $\begin{array}{l}0.783 * \\
(0.326)\end{array}$ \\
\hline Institutional Enrollment (logged) & $\begin{array}{l}-2.017 \\
(5.717)\end{array}$ & $\begin{array}{l}-1.427 \\
(5.670)\end{array}$ & $\begin{array}{l}-1.917 \\
(5.730)\end{array}$ & $\begin{array}{l}-1.151 \\
(5.638)\end{array}$ \\
\hline Instructional Spending per Student (logged) & $\begin{array}{l}5.470 * \\
(2.560)\end{array}$ & $\begin{array}{l}5.079 * \\
(2.562)\end{array}$ & $\begin{array}{l}5.770 * \\
(2.535)\end{array}$ & $\begin{array}{l}5.057 * \\
(2.539)\end{array}$ \\
\hline Percent Undergraduates Part-time & $\begin{array}{l}0.146 \\
(0.130)\end{array}$ & $\begin{array}{l}0.135 \\
(0.130)\end{array}$ & $\begin{array}{l}0.143 \\
(0.130)\end{array}$ & $\begin{array}{l}0.148 \\
(0.128)\end{array}$ \\
\hline In-State Tuition (logged) & $\begin{array}{l}-2.110 \\
(1.863)\end{array}$ & $\begin{array}{l}-2.260 \\
(1.857)\end{array}$ & $\begin{array}{l}-2.039 \\
(1.914)\end{array}$ & $\begin{array}{l}-2.670 \\
(1.857)\end{array}$ \\
\hline Faculty-Student Ratio (logged) & $\begin{array}{l}-0.498 \\
(3.092)\end{array}$ & $\begin{array}{l}-0.850 \\
(3.094)\end{array}$ & $\begin{array}{l}-0.360 \\
(3.124)\end{array}$ & $\begin{array}{l}-0.272 \\
(3.083)\end{array}$ \\
\hline State Unemployment Rate & $\begin{array}{l}0.230 \\
(0.449)\end{array}$ & $\begin{array}{l}0.276 \\
(0.448)\end{array}$ & $\begin{array}{l}0.270 \\
(0.446)\end{array}$ & $\begin{array}{l}0.187 \\
(0.445)\end{array}$ \\
\hline Constant & $\begin{array}{l}62.012 \\
(58.585) \\
\end{array}$ & $\begin{array}{l}61.756 \\
(58.162) \\
\end{array}$ & $\begin{array}{l}57.364 \\
(58.771) \\
\end{array}$ & $\begin{array}{l}61.228 \\
(57.962) \\
\end{array}$ \\
\hline $\mathrm{N}$ & 2653 & 2653 & 2653 & 2653 \\
\hline $\mathrm{R}^{2}$ & .03 & .03 & .03 & .04 \\
\hline Institution Fixed Effects & Yes & Yes & Yes & Yes \\
\hline Year Fixed Effects & Yes & Yes & Yes & Yes \\
\hline
\end{tabular}

$+\mathrm{p}<0.10, * \mathrm{p}<0.05$ 


\begin{tabular}{|c|c|c|c|c|}
\hline & $\begin{array}{c}\text { Any } \\
\text { Premium }\end{array}$ & $\begin{array}{l}\text { Minority } \\
\text { Student } \\
\text { Premium }\end{array}$ & $\begin{array}{l}\text { Low- } \\
\text { Income } \\
\text { Student } \\
\text { Premium }\end{array}$ & $\begin{array}{l}\text { Minority } \\
\text { and Low- } \\
\text { Income } \\
\text { Premium }\end{array}$ \\
\hline Premium Treat $\mathrm{x}$ Post & $\begin{array}{l}0.012 \\
(0.030)\end{array}$ & $\begin{array}{l}0.051 \\
(0.049)\end{array}$ & $\begin{array}{l}-0.084 * \\
(0.036)\end{array}$ & $\begin{array}{l}0.015 \\
(0.053)\end{array}$ \\
\hline Duration of Premium (years) & $\begin{array}{l}-0.000 \\
(0.003)\end{array}$ & $\begin{array}{l}-0.017 * \\
(0.007)\end{array}$ & $\begin{array}{l}0.007 \\
(0.005)\end{array}$ & $\begin{array}{l}-0.029 * \\
(0.011)\end{array}$ \\
\hline Institutional Enrollment (logged) & $\begin{array}{l}1.000^{*} \\
(0.110)\end{array}$ & $\begin{array}{l}1.009 * \\
(0.111)\end{array}$ & $\begin{array}{c}0.995^{*} \\
(0.108)\end{array}$ & $\begin{array}{l}0.999 * \\
(0.110)\end{array}$ \\
\hline Instructional Spending per Student (logged) & $\begin{array}{l}-0.100 \\
(0.061)\end{array}$ & $\begin{array}{l}-0.085 \\
(0.061)\end{array}$ & $\begin{array}{l}-0.098 \\
(0.062)\end{array}$ & $\begin{array}{l}-0.092 \\
(0.060)\end{array}$ \\
\hline Percent Undergraduates Part-time & $\begin{array}{c}0.005^{*} \\
(0.002)\end{array}$ & $\begin{array}{l}0.005^{*} \\
(0.002)\end{array}$ & $\begin{array}{l}0.005^{*} \\
(0.002)\end{array}$ & $\begin{array}{l}0.005^{*} \\
(0.002)\end{array}$ \\
\hline In-State Tuition (logged) & $\begin{array}{l}-0.007 \\
(0.059)\end{array}$ & $\begin{array}{l}-0.004 \\
(0.058)\end{array}$ & $\begin{array}{l}-0.001 \\
(0.057)\end{array}$ & $\begin{array}{l}-0.008 \\
(0.060)\end{array}$ \\
\hline Faculty-Student Ratio (logged) & $\begin{array}{l}0.035^{*} \\
(0.013)\end{array}$ & $\begin{array}{l}0.035^{*} \\
(0.013)\end{array}$ & $\begin{array}{c}0.035^{*} \\
(0.013)\end{array}$ & $\begin{array}{l}0.035^{*} \\
(0.013)\end{array}$ \\
\hline State Unemployment Rate & $\begin{array}{l}-0.012 \\
(0.011)\end{array}$ & $\begin{array}{l}-0.013 \\
(0.011)\end{array}$ & $\begin{array}{l}-0.014 \\
(0.011)\end{array}$ & $\begin{array}{l}-0.013 \\
(0.011)\end{array}$ \\
\hline Constant & $\begin{array}{l}-2.457 * \\
(1.239) \\
\end{array}$ & $\begin{array}{l}-2.670 * \\
(1.242) \\
\end{array}$ & $\begin{array}{l}-2.452 * \\
(1.227) \\
\end{array}$ & $\begin{array}{l}-2.490 * \\
(1.238) \\
\end{array}$ \\
\hline $\mathrm{N}$ & 5522 & 5522 & 5522 & 5522 \\
\hline $\mathrm{R}^{2}$ & 0.58 & 0.58 & 0.58 & 0.58 \\
\hline Institution Fixed Effects & Yes & Yes & Yes & Yes \\
\hline Year Fixed Effects & Yes & Yes & Yes & Yes \\
\hline
\end{tabular}

$+\mathrm{p}<0.10, * \mathrm{p}<0.05$ 


\begin{tabular}{|c|c|c|c|c|}
\hline & $\begin{array}{c}\text { Any } \\
\text { Premium }\end{array}$ & $\begin{array}{l}\text { Minority } \\
\text { Student } \\
\text { Premium }\end{array}$ & $\begin{array}{l}\text { Low- } \\
\text { Income } \\
\text { Student } \\
\text { Premium }\end{array}$ & $\begin{array}{c}\text { Minority } \\
\text { and } \\
\text { Low- } \\
\text { Income } \\
\text { Premium }\end{array}$ \\
\hline Premium Treat $\mathrm{x}$ Post & $\begin{array}{l}-0.040 \\
(0.033)\end{array}$ & $\begin{array}{l}0.042 \\
(0.036)\end{array}$ & $\begin{array}{l}-0.064+ \\
(0.035)\end{array}$ & $\begin{array}{l}0.001 \\
(0.042)\end{array}$ \\
\hline Duration of Premium (years) & $\begin{array}{l}0.006+ \\
(0.003)\end{array}$ & $\begin{array}{l}0.007 \\
(0.005)\end{array}$ & $\begin{array}{l}0.008+ \\
(0.004)\end{array}$ & $\begin{array}{l}0.019 * \\
(0.008)\end{array}$ \\
\hline Institutional Enrollment (logged) & $\begin{array}{c}1.103^{*} \\
(0.089)\end{array}$ & $\begin{array}{c}1.103 * \\
(0.088)\end{array}$ & $\begin{array}{l}1.098 * \\
(0.089)\end{array}$ & $\begin{array}{l}1.107^{*} \\
(0.088)\end{array}$ \\
\hline Instructional Spending per Student (logged) & $\begin{array}{l}-0.008 \\
(0.066)\end{array}$ & $\begin{array}{l}-0.018 \\
(0.067)\end{array}$ & $\begin{array}{l}-0.002 \\
(0.066)\end{array}$ & $\begin{array}{l}-0.012 \\
(0.066)\end{array}$ \\
\hline Percent Undergraduates Part-time & $\begin{array}{l}0.004+ \\
(0.002)\end{array}$ & $\begin{array}{l}0.004 \\
(0.002)\end{array}$ & $\begin{array}{l}0.004+ \\
(0.002)\end{array}$ & $\begin{array}{l}0.004+ \\
(0.002)\end{array}$ \\
\hline In-State Tuition (logged) & $\begin{array}{l}-0.092 * \\
(0.031)\end{array}$ & $\begin{array}{l}-0.088 * \\
(0.031)\end{array}$ & $\begin{array}{l}-0.085^{*} \\
(0.031)\end{array}$ & $\begin{array}{l}-0.090 * \\
(0.032)\end{array}$ \\
\hline Faculty-Student Ratio (logged) & $\begin{array}{l}0.025^{*} \\
(0.011)\end{array}$ & $\begin{array}{l}0.025^{*} \\
(0.011)\end{array}$ & $\begin{array}{l}0.025^{*} \\
(0.011)\end{array}$ & $\begin{array}{l}0.026^{*} \\
(0.011)\end{array}$ \\
\hline State Unemployment Rate & $\begin{array}{l}-0.020+ \\
(0.011)\end{array}$ & $\begin{array}{l}-0.017+ \\
(0.011)\end{array}$ & $\begin{array}{l}-0.020 * \\
(0.010)\end{array}$ & $\begin{array}{l}-0.017+ \\
(0.011)\end{array}$ \\
\hline Constant & $\begin{array}{l}-4.392 * \\
(1.205)\end{array}$ & $\begin{array}{l}-4.356^{*} \\
(1.200)\end{array}$ & $\begin{array}{l}-4.438 * \\
(1.206)\end{array}$ & $\begin{array}{l}-4.430 * \\
(1.194)\end{array}$ \\
\hline $\mathrm{N}$ & 5522 & 5522 & 5522 & 5522 \\
\hline $\mathrm{R}^{2}$ & 0.81 & 0.81 & 0.81 & 0.81 \\
\hline Institution Fixed Effects & Yes & Yes & Yes & Yes \\
\hline Year Fixed Effects & Yes & Yes & Yes & Yes \\
\hline
\end{tabular}

$+\mathrm{p}<0.10, * \mathrm{p}<0.05$ 


\begin{tabular}{|c|c|c|c|c|}
\hline \multicolumn{5}{|c|}{$\begin{array}{l}\text { Table 6: Effect of Performance-Funding Premiums on Low-Income Student } \\
\text { Enrollment, 1997-2014 }\end{array}$} \\
\hline & $\begin{array}{c}\text { Any } \\
\text { Premium }\end{array}$ & $\begin{array}{l}\text { Minority } \\
\text { Student } \\
\text { Premium }\end{array}$ & $\begin{array}{c}\text { Low- } \\
\text { Income } \\
\text { Student } \\
\text { Premium }\end{array}$ & $\begin{array}{l}\text { Minority } \\
\text { and } \\
\text { Low- } \\
\text { Income } \\
\text { Premium }\end{array}$ \\
\hline \multirow[t]{2}{*}{ Premium Treat $\mathrm{x}$ Post } & 0.727 & 0.570 & 0.724 & -0.745 \\
\hline & $(0.444)$ & $(0.614)$ & $(0.457)$ & $(0.627)$ \\
\hline \multirow[t]{2}{*}{ Duration of Premium (years) } & $0.089 *$ & -0.071 & $0.181^{*}$ & $0.295^{*}$ \\
\hline & $(0.044)$ & $(0.104)$ & $(0.045)$ & $(0.145)$ \\
\hline \multirow[t]{2}{*}{ Institutional Enrollment (logged) } & -1.614 & -1.483 & -1.937 & -1.574 \\
\hline & $(1.239)$ & $(1.242)$ & $(1.234)$ & $(1.231)$ \\
\hline \multirow[t]{2}{*}{ Instructional Spending per Student (logged) } & $-1.773+$ & $-1.655+$ & $-1.639+$ & $-1.702+$ \\
\hline & $(0.942)$ & $(0.946)$ & $(0.928)$ & $(0.944)$ \\
\hline \multirow[t]{2}{*}{ Percent Undergraduates Part-time } & 0.031 & 0.022 & 0.032 & 0.026 \\
\hline & $(0.036)$ & $(0.037)$ & $(0.036)$ & $(0.036)$ \\
\hline \multirow[t]{2}{*}{ In-State Tuition (logged) } & -0.595 & -0.413 & -0.451 & -0.550 \\
\hline & $(0.581)$ & $(0.573)$ & $(0.544)$ & $(0.596)$ \\
\hline \multirow[t]{2}{*}{ Faculty-Student Ratio (logged) } & -0.851 & -0.850 & -0.699 & -0.780 \\
\hline & $(0.656)$ & $(0.647)$ & $(0.642)$ & $(0.647)$ \\
\hline \multirow[t]{2}{*}{ State Unemployment Rate } & $0.638^{*}$ & $0.630^{*}$ & $0.617 *$ & $0.635^{*}$ \\
\hline & $(0.135)$ & $(0.136)$ & $(0.134)$ & $(0.136)$ \\
\hline \multirow[t]{2}{*}{ Constant } & $93.165^{*}$ & $90.047 *$ & $93.442 *$ & $91.983^{*}$ \\
\hline & $(17.575)$ & $(17.715)$ & $(17.255)$ & $(17.485)$ \\
\hline $\mathrm{N}$ & 4456 & 4456 & 4456 & 4456 \\
\hline $\mathrm{R}^{2}$ & 0.31 & 0.31 & 0.32 & 0.31 \\
\hline Institution Fixed Effects & Yes & Yes & Yes & Yes \\
\hline Year Fixed Effects & Yes & Yes & Yes & Yes \\
\hline
\end{tabular}

$+\mathrm{p}<0.10, * \mathrm{p}<0.05$ 


\section{References}

Adams, S. J., Heywood, J., Rothstein, R. (2009). Teachers, performance pay, and accountability. Washington, DC: Economic Policy Institute.

Banta, T., Rudolph, L., Dyke, J. Van, \& Fisher, H. (1996). Performance funding comes of age in Tennessee. The Journal of Higher Education, 67(1), 23-45. http://doi.org/10.2307/294390

Bell, D. (2005). Changing organizational stories: The effects of performance-based funding on three community colleges in Florida (Doctoral dissertation). Available from ProQuest Dissertations and Theses database. (UMI No. 3210509)

Berne, R., \& Stiefel, L. (1984). The measurement of equity in school finance: Conceptual, methodological and empirical dimensions. Baltimore, MD: Johns Hopkins University Press.

Bevan, G., \& Hood, C. (2006). What's measured is what matters: Targets and gaming in the English public health care system. Public Administration, 84(3), 517-538

Boilard, S.D. (2016). Connecting state and institutional finance policies for improved higher education outcomes. Lumina Issue Papers. Indianapolis, IN: Lumina Foundation for Education.

Burke, J. C. (Ed.) (2002). Funding public colleges and universities: Popularity, problems, and prospects. Albany, NY: SUNY Press.

Colbeck, C. L. (2002). State policies to improve undergraduate teaching: Administrator and faculty responses. Journal of Higher Education, 73(1), pp. 3-25.

Dougherty, K. J., \& Hong, E. (2006). Performance accountability as imperfect panacea: The community college experience. In T. Bailey \& V. Morest (Eds.), Defending the community college equity agenda (pp. 51-86). Baltimore, MD: Johns Hopkins University Press.

Dougherty, K. J., \& Reddy, V. (2013). Performance funding for higher education: What are the mechanisms? What are the impacts? (ASHE Higher Education Report). San Francisco, CA: Jossey-Bass.

Dougherty, K. J., Jones, S. M., Lahr, H., Natow, R. S., Pheatt, L., \& Reddy, V. (2014). Performance Funding for Higher Education: Forms, Origins, Impacts, and Futures. Annals of the American Academy of Political and Social Science, 655, pp. 163-184.

Dowd, A. C. (2003). From Access to Outcome Equity: Revitalizing the Democratic Mission of the Community College. The Annals of the American Academy of Political and Social Science, 586(1), 92-119. http://doi.org/10.1177/0095399702250214

Eisenhardt, K. M. (1989). Agency theory: An assessment and review. Academy of Management Review, 14(1), 57-74.

Friedel, J. N., Thornton, Z. M., D’Amico, M. M., \& Katsinas, S. G. (2013). Performance-Based Funding: The National Landscape. Tuscaloosa, AL: Education Policy Center.

Gándara, D. (2016). Constructing "winners and losers" [electronic resource]: an analysis of higher education performance funding policy designs in Colorado and Texas (Doctoral dissertation). Available from University of Georgia Electronic Theses and Dissertations database (Call No. Internet LXC16 2016 Gandara, D.)

Gerrish, E. (2016). The impact of performance management on performance in public organizations: A Meta-Analysis. Public Administration Review, 76(1), 48-66.

Golden, M. M. (2000). What motivates bureaucrats?: Politics and administration during the Reagan years. Columbia University Press.

Hearn, J. C., McLendon, M. K., \& Mokher, C. G. (2008). Accounting for student success: An empirical analysis of the origins and spread of state student unit-record systems. Research in Higher Education, 49(8), 665-683. http://doi.org/10.1007/s11162-008-9101-z 
Heckman, J. J., Heinrich, C., \& Smith, J. (2002). The performance of performance standards. The Journal of Human Resources, 37(4), 778-811.

Hillman, N. (2016). Why performance-based college funding doesn't work. New York, NY: The Century Foundation.

Hillman, N., Tandberg, D., \& Gross, J. (2014). Performance funding in higher education: Do financial incentives impact college completions? The Journal of Higher Education, 85(6), 826-857. http://doi.org/10.1353/jhe.2014.0031

Hillman, N. W., Tandberg, D. A., \& Fryar, A. H. (2015). Evaluating the impacts of "new" performance funding in higher education. Educational Evaluation and Policy Analysis, 37(4), 501-519.

Hood, C. (1995). Contemporary public management: a new global paradigm? Public Policy and Administration, 10(2), 104-117.

Howlett, M. (2005). What is a policy instruments? Tools, mixes and implementations styles. In F.P. Eliadis, M.M. Hill, \& M. Howlett (Eds.), Designing government: from instruments to governance (pp. 31-50). Montréal: McGill-Queen's University Press.

Jacob, B. A. (2005). Accountability, incentives and behavior: The impact of high-stakes testing in the Chicago Public Schools. Journal of Public Economics, 89(5-6), 761-796.

Jenkins, D., Ellwein, T., \& Boswell, K. (2009). Formative evaluation of the Student Achievement Initiative "learning year" (Report to the Washington State Board of Community and Technical Colleges and College Spark Washington). New York, NY: Community College Research Center.

Jones, T. (2014). Performance Funding at MSIs: Considerations and Possible Measures for Public Minority-Serving Institutions. Atlanta, GA: Southern Education Foundation. Retrieved from http://www.southerneducation.org/Our-Strategies/Research-andPublications/Performance-Funding-at-MSIs.aspx

Kastner, J. C. (2000). Tennessee's Performance Funding Program: An analysis of planning for improvement by two-year institutions (Doctoral dissertation). Available from ProQuest Dissertations and Theses database. (UMI No. AAT 9967040.

Kelchen, R., \& Stedrak, L. J. (2016). Does performance-based funding affect colleges' financial priorities? Journal of Education Finance, 41(3), 302-321. Retrieved from https://muse.jhu.edu/article/613777

Kivistö, J. (2008). An assessment of agency theory as a framework for the governmentuniversity relationship. Journal of Higher Education Policy and Management, 30(4), 339350. doi:10.1080/13600800802383018

Klarner, C. (2016). State partisan balance data, 1937-2015. http://klarnerpolitics.com/kp-datasetpage.html.

Lahr, H., Pheatt, L., Dougherty, K. J., Jones, S. M., Natow, R. S., \& Reddy, V. (2014). Unintended Impacts of Performance Funding on Community Colleges and Universities in Three States [Working Paper No. 78]. Community College Research Center.

Li, A.Y., Zumeta, W. (2016). Performance Funding on the Ground: Campus Responses and Perspectives in Two States. Research Dialogue. New York, NY: TIAA

Liu, V. Y. T., Belfield, C. R., Trimble, M. J. (2015). The medium-term labor market returns to community college awards: Evidence from North Carolina. Economics of Education Review, 44(C), 42-55. 
McDonnell, L. M., \& Elmore, R. F. (1987). Getting the job done: alternative policy instruments. Educational Evaluation and Policy Analysis, 9(2), 133-152. http://doi.org/10.3102/01623737009002133

McKeown-Moak, M. P. (1999). Higher education funding formulas. New Directions for Higher Education, (107), 99-107.

McKinney, L., \& Hagedorn, L. S. (2017). Performance-Based Funding for Community Colleges: Are Colleges Disadvantaged by Serving the Most Disadvantaged Students? The Journal of Higher Education, 88(2), 159-182.

Miller, G. J. (2005). The political evolution of principal-agent models. Annual Review of Political Science, 8, 203-225.

Miller, T. (2016). Higher education outcomes-based funding models and academic quality. Lumina issue papers. Indianapolis, IN: Lumina Foundation.

Moe, T. M. (1984). The new economics of organization. American Journal of Political Science, 28(4), 739-777.

National Conference of State Legislatures. (2014). Performance-based funding for higher education. Retrieved from http://www.ncsl.org/research/education/performancefunding.aspx.

Ness, E.C. Deupree, M. Gándara, D. (2015). Campus Responses to Tennessee’s 2010 Complete College Tennessee Act and Outcomes-Based Funding Formula. Retrieved from https://www.tn.gov/assets/entities/thec/attachments/FordFoundationPaper.pdf

Rutherford, A., \& Rabovsky, T. (2014). Evaluating impacts of performance funding policies on student outcomes in higher education. The ANNALS of the American Academy of Political and Social Science, 655(1), 185-208. http://doi.org/10.1177/0002716214541048

Sanford, T., \& Hunter, J. M. (2011). Impact of performance-funding on retention and graduation rates. Education Policy Analysis Archives, 19(33), 33. Retrieved from http://epaa.asu.edu/ojs/article/view/949

Schneider, A., \& Ingram, H. (1990). Behavioral assumptions of policy tools. The Journal of Politics, 52(2), 510. http://doi.org/10.2307/2131904

Shen, Y. (2003). Selection incentives in a performance-based contracting system. Health Services Research, 38(2), 535-552.

Shin, J. C. (2010). Impacts of performance-based accountability on institutional performance in the U.S. Higher Education, 60(1), 47-68.

Shin, J. C., \& Milton, S. (2004). The effects of performance budgeting and funding programs on graduation rate in public four-year colleges and universities. Education Policy Analysis Archives, 12, 1-26.

Snyder, M. (2015). Driving better outcomes: Typology and principles to inform outcomes-based funding models. Washington, D.C.: HCM Strategists

Stone, D. A. (2002). Policy paradox: The art of political decision making (p. 448). New York: Norton.

Tandberg, D. A. (2010). Politics, interest groups and state funding of public higher education. Research in Higher Education, 51(5), 416-450.

Tandberg, D. A., \& Hillman, N. W. (2014). State higher education performance funding: Data, outcomes, and policy implications. Journal of Education Finance, 39(3), 222-243.

Tandberg, D. A., Hillman, N., \& Barakat, M. (2014). State Higher Education Performance Funding for Community Colleges: Diverse Effects and Policy Implications. Teachers College Record, 116(12), p. 1-31. 
Tennessee Higher Education Commission. (2015). 2015-20 Outcomes Based Funding Formula. Nashville, TN: Tennessee Higher Education Commission. Retrieved from https://www.tn.gov/thec/article/2015-20-funding-formula

Thomas, S. L., \& Zhang, L. (2005). Post-baccalaureate wage growth within four years of graduation: The effects of college quality and college major. Research in Higher Education, 46(4), 437-459.

Tierney, S. (2014). Performance-based funding and student-centered higher education. The Evolllution. Retrieved from http://evolllution.com/opinions/performance-based-fundingstudent-centered-higher-education/

Umbricht, M. R., Fernandez, F., \& Ortagus, J. C. (2015). An examination of the (un) intended consequences of performance funding in higher education. Educational Policy, 0895904815614398.

Van Slyke, D. M. (2007). Agents or stewards: Using theory to understand the governmentnonprofit social service contracting relationship. Journal of Public Administration Research and Theory, 17(2), 157-187.

Volkwein, J. F., \& Tandberg, D. A. (2008). Measuring up: Examining the connections among state structural characteristics, regulatory practices, and performance. Research in Higher Education, 49(2), 180-197.

Werner, R. M., Kolstad, J. T., Stuart, E. A., \& Polsky, D. (2011). The effect of pay-forperformance in hospitals: Lessons for quality improvement. Health Affairs, 30(4), 690698.

Wooldridge, J. M. (2012). Econometric analysis of cross section and panel data. Cambridge, MA: MIT Press.

Zhang, L. (2005). Advance to graduate education: The effect of college quality and undergraduate majors. The Review of Higher Education, 28(3), 313-338. 